\title{
Okul öncesi Dönem Çocuklarının Çevre Sorunları Kavramına Yönelik Metaforik
} Algıları ve Görüşleri ${ }^{1}$

\author{
Metaphoric Perceptions and Views of Preschool Children' on the Concept of Environmental
}

Problems

\section{Hakan Şevki AYVACI' ${ }^{2}$ Sinan BÜLBÜL ${ }^{3}$, Gürhan BEBEK ${ }^{4}$}

\begin{abstract}
Öz
$\mathrm{Bu}$ araştırmanın amacı okul öncesi dönem çocuklarının çevre sorunları kavramına yönelik metaforik algı ve görüşlerinin belirlenmesidir. Bu amaç doğrultusunda özel bir anaokulunda öğrenim görmekte olan 58-66 aylık toplam 14 çocukla araştırma yürütülmüştür. Araştırma nitel desende olup fenomenografik araştırma yöntemi ile gerçekleştirilmiştir. Çocuklarla gerçekleştirilen görüşmelerde “Çevre sorunu ... gibidir. Çünkü ..." ifadesini tamamlayacak şekilde cevaplar vermeleri istenmiştir. Buna ek olarak çevre sorunu kavramına yönelik görüşlerini ortaya çıkaracak sorular da yöneltilmiştir. Elde edilen veriler kayıt altına alınarak tümevarımsal bir yaklaşımla içerik analizine tabii tutulmuştur. Analiz kapsamında kod ve temalar belirlenerek metaforlar ve görüşler tespit edilmiştir. Araştırmadan elde edilen bulgulara göre okul öncesi çocuklarının çevre sorunu kavramına yönelik kötü koku, ağlayan bitki, kara bulut, mutsuz hayvan ve mide bulantısı şeklinde toplam beş metafora sahip oldukları belirlenmiştir. Çocuklar çevre sorunlarının insanlardan, hayvanlardan ve araçlardan kaynaklandıklarını düşünmektedirler. Çevre sorunlarının en çok insanları, hayvanları ve havayı etkilediğini belirten çocuklar, çevre sorunlarının önlenmesi amacıyla en çok kural koyma, ceza verme, insanları eğitme gibi önerilerde bulunmuşlardır. Araştırma neticesinde okul öncesi dönem çocuklarının kısıtlı metaforlara sahip oldukları sonucuna ulaşılmış ve bu doğrultuda okul öncesinde verilecek çevre eğitimine ilişkin önerilerde bulunulmuștur.
\end{abstract}

Anahtar Kelimeler

Okul öncesi

Çocuk

Çevre

Metafor

\section{Abstract}

The purpose of this research is to determine the metaphorical perceptions and opinions on the concept of pre-school children's environmental problems. For this purpose, a study was conducted with a total of 14 children aged 58-66 months, studying in a private kindergarten. The research has a qualitative design and was carried out by phenomenographic research method. In the interviews conducted with the children, they were asked to give answers in a way that complements the statement "Environmental problem is like ... Because...". In addition, questions were asked to reveal their views on the concept of environmental problems. The data obtained were recorded and subjected to content analysis with an inductive approach. Within the scope of the analysis, codes and themes were determined and metaphors and opinions were put forward. According to the findings obtained from the research; It has been determined that preschool children have a total of six metaphors about the concept of environmental problem: bad odor, crying plant, black cloud, unhappy animals, and nausea. Children think that environmental problems are caused by people, animals, and vehicles. Stating that environmental problems mostly affect people, animals, and the air; To prevent environmental problems, they mostly made suggestions such as setting rules, punishing, and educating people. As a result of the research, it was concluded that preschool children had limited metaphors, and in this direction, suggestions were made regarding the environmental education to be given in the preschool period.

Keywords

Preschool

Child

Environment

Metaphor

\begin{tabular}{lll}
\hline Başvuru Tarihi/Received & Kabul Tarihi /Accepted \\
19.04.2021 & 27.05.2021
\end{tabular}
19.04.2021 27.05.2021

\section{Suggested APA Citation/Önerilen APA Atıf Biçimi:}

Ayvacı, H. Ş., Bülbül, S., \& Bebek, G. (2021). Metaphoric perceptions and views of preschool children' on the concept of environmental problems. Manisa Celal Bayar University Journal of the Faculty of Education, 9(1), 117-132. https://doi.org/10.52826/mcbuefd.922632.

\footnotetext{
${ }^{1}$ Bu çalışmada 2020 yılı öncesine ait veriler kullanıldığı yazarlar tarafından beyan edildiği için etik kurul raporu gerekmemektedir.

2 Sorumlu Yazar, Prof. Dr., Trabzon Üniversitesi, Fatih Eğitim Fakültesi, Matematik ve Fen Bilimleri Eğitimi Bölümü, Trabzon, TÜRKIYE; (iD https://orcid.org/0000-0002-3181-3923

${ }^{3}$ Dr., Trabzon Üniversitesi, Fatih Eğitim Fakültesi, Matematik ve Fen Bilimleri Eğitimi Bölümü, Trabzon, TÜRKIYE; (DD https://orcid.org/00000003-1974-781X

4 Öğr. Gör. Dr., Trabzon Üniversitesi, Rektörlük, Trabzon, TÜRKIYE; (D) https://orcid.org/0000-0003-4862-5782
} 


\section{GİRIŞ}

Canlılığın var olduğu bilinen tek gezegen olan Dünya, artan çevre sorunlarıla birlikte her geçen gün yaşanılması daha da zor bir hal almaya başlamıştır. Özellikle sanayi devrimi sonrası gerçekleşen teknolojik ilerleme hareketleri ve bireylerin yaşam standartlarını yükseltmeye yönelik çabalar, sera gazlarının atmosfere kontrolsüz bir şekilde salınarak, küresel ısınma olarak nitelendirilen iklim değişikliklerinin bütün canlılığı tehdit eder bir hale gelmesine sebep olmuştur (Akın, 2006; Bozoğlu, Keskin ve Çavdar, 2002; Öztürk, 2002). Küresel ısınmanın olumsuz etkileri ve insan kaynaklı sebeplerle birlikte, her geçen zamanda onlarca canlı türünün yok olduğu bilinmekte ve bu sayının ileriki süreçte iki ya da üç katına çıkacağı tahmin edilmektedir (des Jardins, 2006). Aşırı kirlilikten kaynaklı olarak bozulan doğal denge de giderek kendini yenileyebilme kabiliyetini kaybetmektedir. İnsanlara göre doğada var olan her şey plansız bir şekilde alınabilir ve tüketilebilirdir. Bu durum gezegenimizin sınırsız bir kaynak deposu olarak görülmesinden ileri gelmekte; plansız ve özensiz bir kaynak tüketimine sebep olmaktadır. İnsanın doğaya bakış açısının bahsedilen şekilde olmasının temelinde eğitim-öğretim süreçleri, yaşanılan toplumun kültürel bakış açıları, yetişme koşulları, hukuk ve ahlak anlayışları gibi farklı unsurlar belirleyicidir (Atasoy, 2006). Bu unsurlardan en önemlisinin eğitim olduğu ifade edilebilir. Çünkü bireylerin çevre ve doğaya yönelik antroposentrik (insan merkezli) davranışlarının altında yatan en temel sorunun ve bu sorunun çözümünün de eğitim olduğu belirtilmektedir. Bu davranış biçimlerinin düzeltilmesini gelişen teknoloji ve yasalarla sağlamak eğitim olmadan mümkün değildir. Davranış biçimlerine yönelik değişimi sağlayabilmek için bilgi, tutum ve değer yargılarına ilişkin değişimin sağlanması gerekmektedir. Ekosentrik (doğa merkezli) davranışların sergilenmesini sağlayacak bilgi, tutum ve değer yargılarının oluşması da ancak çevre eğitimi ile sağlanabilir. (Erten, 2004). Dolayısıyla, çevresel sorunlara ilişkin farkındalığın artmasıyla birlikte, bireylere verilecek çevre eğitimine olan ihtiyaç da arttırdığı görülmektedir (Gülay ve Önder, 2011).

Küresel iklim sorunlarının ciddi sonuçlarının gözlemlendiği bir dünyaya gelen çocukların, çevresel sorunlara ilişkin farkındalıklarının yüksek, davranışlarının daha bilinçli ve duyarlı şekilde olması beklenmektedir (Hedefalk, Almqvist ve Östman, 2014). Bu duruma istinaden, bireylere verilecek olan çevre eğitiminin okul öncesi dönemde başlaması gerektiği söylenebilir. Çünkü Basile'ye (2000) göre doğaya yönelik tutumlar ve çevreye yönelik davranışların gelişimi okul öncesi dönemde şekillenmeye başlamaktadır. Benzer şekilde Wilson (1996) okul öncesi dönemde verilecek çevre eğitiminin, çocukların yaşamları boyunca sergileyeceği çevresel tutumların ve davranışların olumlu yönde gelişeceğini belirtmektedir. Çevre eğitiminin, kişiliğin şekillendiği okul öncesi dönemle birlikte başlaması gerektiğini ifade eden Gülay-Ogelman ve Güngör (2015), çocuğun bu dönemde kazanacağı tutum ve davranışların yetişkinlik dönemindeki kişilik yapısını oluşturacağını belirtmektedir. Kuzu (2008) ise bireyin çevreye yönelik kazanacağı bilincin temellerinin aile eğitimiyle atıldığını ifade etmektedir. Benzer şekilde Güler (2008), çocukların rol model olarak anne ve babalarını örnek aldıklarını ifade etmekte ve onları taklit ederek tutum ve davranış geliştirdiklerini belirtmektedir. Fakat aile her zaman çocuğa ihtiyaç duyulan bu eğitimi verememektedir. Bu durumda ailenin sosyo-ekonomik düzeyinin yanı sıra çevreye yönelik farkındalık seviyelerinin de önemli olduğu ifade edilmekte, dolayısıyla çocuklara verilecek çevre eğitiminin formal bir çerçevede sunulmasının önemli olduğuna değinilmektedir (Taşkın ve Şahin, 2008). Dolayısıyla bireylerin çevreye yönelik olumlu tutum, davranış, yüksek bilgi düzeyi ve çevresel sorunlara ilişkin farkındalıklara sahip olabilmeleri ancak çocukluk döneminde başlayacak bir çevre eğitimi ile mümkün olacaktır. Bu noktada verilecek eğitimin yapısı, özellikleri ve bireye nasıl aktarılması gerektiği sorularıyla karşılaşılabilir. Özellikle okul öncesi dönem söz konusu olduğunda, çocuklara kazandırılacak bilgilerin ve davranış şekillerinin aktarılması, programlarının bu çerçevede düzenlenmesi önemli unsurlar olarak görülmektedir.

Çevre eğitiminin okul öncesi dönemde başlamasını belirten pek çok araştırma literatürde yer almaktadır (Basile, 2000; Gülay-Ogelman ve Güngör, 2015; Hedefalk vd., 2014; Wilson, 1996). Çevre eğitiminin kuramsal yapısının oluşturulması ve buna ek olarak uygulama sürecinin nitelikli olmasını sağlayabilmek için, öncelikle bireyin zihinsel süreçlerinin ve çevreye yönelik algılarının belirlenmesi önem arz etmektedir. Eğitim literatürü incelendiğinde bu algıların belirlenmesinde kullanılan yollarından birisinin metaforlar olduğu görülmektedir 
(Akgün, Duruk ve Gülmez-Güngörmez 2016; Aydın, 2011; Çil, 2018; Derman, 2014; Kızılay, 2020; Toplu, 2015). Aşağıda metafor kavramına ilişkin açıklamalara yer verilmiştir.

\section{Metafor Kavramı}

Metafor kavramının literatürde farklı tanımlanmaları olduğu görülmektedir. Morgan'a (1993) göre metafor bir düşünce ve görme biçimidir. Lakoff ve Johnson (2005) ise metaforu, zihinsel bir gelişim aracı olarak değerlendirmekte, bireyin kavrayışının bir şekli olduğunu, sadece söz figürü olmadığını, aynı zamanda düşüncenin de bir unsuru olduğunu belirtmektedir. Vosniadou ve Ortony (1989) ise metaforları bir deneyimin başka bir deneyimin kavramları ile belirtilmesi yoluyla karmaşık konuların ya da yeni deneyimlenecek durumların daha kolay bir şekilde anlaşılabilmesini sağlayan analojiler olduğunu ifade etmektedir. Metaforlar bir olgunun başka bir olgu gibi olduğunun açı veya örtük bir biçimde belirtilmesiyle oluşur. Bu durum metaforların güçlü birer zihinsel model olmalarını sağlayarak, iki farklı ve benzemeyen olgu arasında ilişki kurulmasını, bir zihinsel imajın başka bir zihinsel imajın üzerine yansıtılmasına imkân sağlar. Böylece birey, zihnindeki anlayışı (kavrayış) başka bir anlayışa yönelterek, belli bir olguyu başka bir olgu olarak görebilir (Saban, 2008). Bir metaforun üç temel öğesi bulunmaktadır: metaforun konusu, metaforun kaynağı ve kaynaktan konuya atfedilmesi düşünülen özellikler (Forceville, 2002). Örneğin “Atmosfer, Dünya'mızı koruyan bir battaniye gibidir." cümlesinde atmosfer metafor konusunu; Dünya'mızı koruyan bir battaniye ifadesi metaforun kaynağını; battaniyenin koruyuculuğu ve sıcak tutma özelliği ise kaynaktan konuya atfedilen özelliği belirtmektedir.

\section{Okul öncesi Dönem Çocukları ve Çevreye İlişkin Literatür Taraması}

Okul öncesi dönemi, çevreye yönelik bilgi, tutum, farkındalık ve beceri kazandırılması noktasında bir temel teşkil etmektedir. Bu bağlamda literatürde okul öncesi çocukları ve çevreye ilişkin çeşitli çalışmalara rastlanmaktadır. Taşkın ve Şahin (2008), dört anasınıfında yer alan toplan 44 çocukla gerçekleştirmiş oldukları çalışmalarında, çevre kavramının çocukların yaşadıkları yerleşim birimi ve sosyo-ekonomik düzeye göre farklılaştığını belirtmektedirler. Ek olarak orta ve üst gelir grubu ailelerin çocuklarının çevresel sorunlara ilişkin daha geniş bir farkındalık düzeylerinin olduğunu tespit etmişlerdir. Şallı (2011) okul öncesi dönem çocuklarına geri dönüşüm kavramını kazandırmak amacıyla proje yaklaşımı çerçevesinde çeşitli etkinlikler uygulamıştır. Bu etkinlikleri gerçekleştiren deney grubu çocuklarında, kontrol grubunda yer alanlara göre geri dönüşüm kavramına yönelik kazanımla düzeylerinin daha yüksek olduğu belirlenmiştir. Ogelman, Önder, Durkan ve Erol (2015) ise 65 çocukla yürütmüş oldukları proje etkinlikleri neticesinde, çocuklarda toprağa ilişkin bilgi düzeylerinin arttığı ve çevreye yönelik olumlu tutumlar kazandıklarını ifade etmişlerdir. Literatürde, doğa ile kurulan yüksek etkileşim ve yaparak-yaşayarak gerçekleştirilen uygulamalar neticesinde çocukların çevre algılarına yönelik gelişimin arttığı belirtilmektedir (Özdemir ve Uzun, 2006). Phenice ve Griffore (2003), doğa ile iç içe geçirilmiş bir çocukluk döneminin, çevreyi tanımada önemli olduğunu vurgulayarak; aktif öğrenme ve doğayla doğrudan etkileşim kuran çocukların çevreye yönelik algılarının daha yüksek olduğunu ifade etmişlerdir. Loughland, Reid, Walker ve Petocz, (2003) ise çocukların çevreye yönelik algılarının sosyo-ekonomik düzey, eğitim programı, cinsiyet ve yaşanılan yere göre etkilendiği belirlemiştir.

\section{Araştırmanın Amacı ve Gerekçesi}

Çevre ve doğaya yönelik algıların gelişiminde çocukluk dönemindeki zihinsel gelişim ve görsel algılama büyük bir öneme sahiptir. Çocukluk dönemindeki bireylerin zihinsel algılayışları (kavramaları) görsel süreçler ve durumlar çerçevesinde şekillenmektedir. Görsel algıların zihinsel işleyişi sırasında eksik kalan ya da anlamlandırılamayan öğeler, çocukların zihinleri tarafından tamamlanmaktadır (Ferah, 2007). Buna ek olarak bu dönemde algı yoluyla elde edilen deneyimler, ömür boyu sürecek davranış ve tutumları şekillendirmektedir (Phenice ve Griffore, 2003). Bu nedenle, eğitim sisteminin temeli oluşturan okul öncesi dönemdeki çocukların çevre algısı yadsınamaz bir öneme sahiptir; çünkü çocuk ile içinde bulunduğu ortam-çevre ayrılmaz bir bütündür (Deniz, 2020). Doğal çevrenin kendisine ait sorunlar da içinde yaşayan tüm canlıları etkilemekte ve algılarını etkilemektedir. 
Özellikle, günden güne etkisini hissettirmeye başlayan çevre sorunlarına bağlı iklim değişiklikleri, doğal çevrenin insanlar tarafından bir düşman gibi algılanmasına sebep olabilmektedir. Okul öncesi dönemde bulunan ve bu küresel çevre sorunlarıyla henüz çocukluk döneminde karşılaşan bireylerin mevcut durumu algılayış biçimleri ve bunların değerlendirilmesi, onlarda gelişmesi beklenen olumlu tutum ve davranışlara yönelik ışık tutması açısından oldukça öneme sahiptir. Çevre sorunları kavramının çocukların zihinlerinde oluşturacağı metaforlar, ileride onların bu kavrama yönelik daha somut adımlar atmalarını, çevresel farkındalıkları yüksek bir şekilde davranışlar kazanmalarını sağlayacaktır. Dolayısıyla bu araştırmanın amacı okul öncesi dönem çocuklarının çevre sorunları kavramına yönelik metaforik alg1 ve görüşlerinin belirlenmesidir.

\section{YÖNTEM}

Araştırma okul öncesi dönem çocuklarının çevre sorunları kavramına yönelik metaforik algılarını ve görüşlerini belirlemeyi amaçladı̆̆ından, nitel araştırma yöntemlerinden fenomenografik araştırma yöntemi ile yürütülmüştür. Bu araştırma yöntemi, bireyin yaşadığı ortamda, farklı bakış açılarından algıladığı, deneyimlediği, yapılandırdığı, kavramsallaştırdığı veya anladığı bir olguyu nitel yollar kullanarak belirlemek için kullanılmaktadır (Marton, 1986). Fenomenografik araştırma için veri toplama yöntemi olarak, katılımcılarla bireysel görüşmeler ya da grup görüşmeleri ile gözlemler ve yazılı yanıtlar kullanılabilir (Çepni, 2010).

\section{Çalışma Grubu}

Araştırmanın çalışma grubunu 2018-2019 bahar yarıyılında Trabzon il merkezinde yer alan özel bir okulun anaokulunda öğrenim görmekte olan, 58-66 ay aralığındaki yedisi kız yedisi erkek olmak üzere toplam 14 çocuk oluşturmaktadır. Araştırmanın etik kuralları gereğince çocuklardan kendilerine renkleri içermek koşuluyla takma isim koymaları talep edilmiş ve isimler çocuğun tanımlanmasında kullanılan kodlar olarak kullanılmıştır. Çocukların kendilerine seçmiş oldukları renk kodları Tablo 1'de gösterilmiştir.

Tablo 1. Katılımcıların Kendilerini Tanımlamak İçin Seçmiş Oldukları Renk Kodları

\begin{tabular}{|c|c|c|c|c|c|}
\hline Katılımcı No & Cinsiyet & Kod & Katılımc1 No & Cinsiyet & Kod \\
\hline 1 & Erkek & Mavi & 8 & $\mathrm{~K} 1 \mathrm{z}$ & Sar1 \\
\hline 2 & Erkek & Lacivert & 9 & $\mathrm{~K} 1 \mathrm{z}$ & Turuncu \\
\hline 3 & $\mathrm{~K}_{1 z}$ & Pembe & 10 & Erkek & Kahverengi \\
\hline 4 & $\mathrm{~K}_{1 z}$ & Mor & 11 & Erkek & Yeşil \\
\hline 5 & Erkek & Siyah & 12 & $\mathrm{~K} 1 \mathrm{z}$ & Bordo \\
\hline 6 & Erkek & Beyaz & 13 & $\mathrm{~K}_{1 \mathrm{Z}}$ & Bej \\
\hline 7 & $\mathrm{~K}_{1 \mathrm{Z}}$ & Kırmız1 & 14 & Erkek & Gri \\
\hline
\end{tabular}

\section{Uygulama Süreci ve Veri Toplama Aracı}

Fenomenografik yöntemin tercih edildiği araştırmalarda bireysel görüşmelerden elde edilen veri toplama teknikleri sıklıkla tercih edilmektedir (Marton, 1994). Bu görüşme tekniklerinin informal, rehberli ve yapılandırılmış olmak üzere üç farklı türünün olduğu ifade edilmektedir (Vanderstoep ve Johnson, 2009). Bu araştırmada hem yapılandırılmış görüşme türünün düzen ve sistematiğini içinde bulunduran hem de informal görüşme türünün araştırmacıya sağladığı serbest özellikleri bünyesinde bulundurmasından ötürü rehberli görüşme tekniği ile veriler toplanmıştır. Bu bağlamda çevre sorunları kavramına yönelik metaforik algıları belirlemek için cümlelerden ve görüşlerini belirlemek için ise sorulardan oluşan form geliştirilmiştir. Formda yer alan metafor cümlesi "Çevre sorunlarl, ... gibidir. Çünkü ..." şeklinde iken görüşleri belirlemek için kullanılan sorular ise "Çevre sorunlarında etkili olan durumlar nelerdir? Neden böyle düşünüyorsun?", "Çevre sorunlarının etkisi hakkında neler düşünüyorsun? Çevre sorunlarından neler/kimler etkilenir?" ve "Çevre sorunlarını önüne geçebilmek için neler yapılabilir? Nelere dikkate etmek gerekir?" şeklindedir. Görüldüğü üzere cümleler ve sorular çevre sorunu kavramı, çevre sorununa etki eden faktörler, çevre sorunun etkileri ve çevre sorunları gidermeye yönelik öneriler olmak üzere dört tema altında 
toplanabilmektedir. Taslak olarak hazırlanan sorular fen bilimleri eğitiminde görev yapmakta olan iki akademisyen tarafından incelenmiş, kendilerinden alınan dönütler çerçevesinde düzenlemeler gerçekleştirilmiştir.

Bu düzenlemeler ile oluşturulmuş taslak sorular okul öncesi eğitiminde görev yapmakta olan bir akademisyen tarafından tekrar incelenmiş ve sorulara son hali verilerek uygulama hazır hale getirilmiştir. Çevre sorunları kavramına ilişkin çocukların metaforik algılarını ve görüşlerini belirlemek için uygulama süreci aşağıdaki şekilde yürütülmüştür.

1. 58-66 aylık çocukların çevre konusu ile ilgili farkındalıklarının olup olmadığı ve bu konuda etkinlikler yürütüp yürütmedikleri denetlenmiştir. Elde edilen veriler doğrultusunda çocukların çevre konusunda farkındalıklarının olduğu ve anaokulunda çevre ile ilgili çeşitli etkinlikler yerine getirdikleri tespit edilmiştir. Bu bağlamda da çocukların çevre sorunlarına yönelik metaforik algılarının ve görüşlerinin değerlendirilebileceği fikrine varılmıştır.

2. Çocukların daha önceden metaforik algı konusunda çalışma ile karşılaşmamış olma ihtimaline karşı sınıfta bulunan öğretmen vasıtası ile çocuklara örnekler sunulmuştur. Süreçte çocuklara sunulan örneklerden bazıları şu şekildedir: "Doğa, yeşil bir ev gibidir. Çünkü, tıpkı evlerimizde olduğu gibi onun da içinde canlılar barımmaktadır." ve "Zaman, su gibidir. Çünkü her ikisi de akıp gider." Sunulan örneklere bağlı olarak araştırmacılara tarafından çocuklara yöneltilecek dört adet metafor cümlesinde bu örneklere benzer nitelikte cevaplar vermeleri istenmiş ve tıpkı örneklerdeki gibi benzetim yapmaları ve bu benzetimleri gerekçelendirmeleri gerektiği dile getirilmiştir.

3. Her bir çocukla yaklaşık olarak 10-15 dakikalık görüşmeler gerçekleştirilmiştir. Toplamda 14 çocukla yürütülen soru-cevap süreci toplamda yaklaşık olarak üç saat sürmüştür. Çocukların yazma kabiliyetleri olmadığı için soru-cevap sürecinde bir araştırmacı soruları yöneltirken diğer araştırmacı notlar almıştır. Alınan notlarda eksik olabilme ihtimalini önleme adına da çocukların ifadeleri tekrarlanarak teyit edilerek veri kaybı minimalize edilmeye çalışılmışır.

4. Araştırma sürecinde okul öncesi çocukları ile çalışmasından dolayı, ailelere çalışmanın amaç ve kapsamına ilişkin birer yazı gönderilmiş; sınıf içerisinde hiçbir şekilde video ve ses kaydı alınmayacağı, çocukların kimlik bilgilerinin paylaşılmayacağına dair bilgilendirmeler yapılmıştır. Görüşmeler sırasında rahat olmalarını sağlayacak unsurlar yerine getirilmiştir. Görüşmeler bireysel olarak gerçekleştirilmiş ve çocukların birbirilerine olacak muhtemel etkileşimlerinin önüne geçilmiştir.

\section{Verilerin Analizi}

Gerçekleştirilen görüşmelerden elde edilen veriler transkript edilerek bilgisayar ortamına metin olarak aktarılmıştır. Elde edilen veriler analiz için uygun hale getirildikten sonra iki araştırmacı tarafından bağımsız olarak analiz edilmiştir. Verilerin analizin sürecinde içerik analizinden yararlanılarak tümevarımsal bir yol izlenmiştir. Bu bağlamda özel ifadelerden genel ifadelere giden bir analiz süreci oluşturulmuştur. Hatch'e (2002) göre tümevarımsal analiz, anlamlar belli bazı öğelerle başlayıp, bu öğeler arasındaki ilişkiler keşfedilerek gerçekleştirilir. Analiz sürecinde çerçeve olarak çevre sorunları kavramı belirlenmiştir. Küresel ısınma kavram çerçevesi bağlamında ilişkili olan analiz birimleri kodlar olarak belirlenmiştir. Bu kodlamalar daha sonra birbirileriyle olan ilişkilerine göre kategorilendirilmiştir. Kodları ve kategorileri daha iyi açıklayabilmek için doğrudan alıntılar ile bulgular bölümü oluşturulmuştur.

\section{Araştırmanın İnanırlığı ve Tutarlığı}

Nitel araştırmalar, nicel araştırmalara göre geçerlik ve güvenirlik unsurlarında bazı farklılıklar içermektedir. Bu unsurlar inandırıcılık, doğrulanabilirlik, tutarlılık ve uygulanabilirlik olarak ifade edilmektedir (Lincoln ve Guba, 1985). Bu doğrultuda araştırmada inandırıcılık için elde edilen bulgulardan örnekler rastgele iki çocuk ile tekrar görüşülmüş, ifade ettikleri anlamları taşıyıp taşımadıkları sorulmuştur. Elde edilen verilerin analizinde araştırmacı yorumlar en aza indirilmiş, öznel öğelere yer verilmeyerek uygulanabilirlik unsuru sağlanmaya çalışılmıştır. Veri 
toplama sürecinde sorulacak sorulan hazırlanması, verilerin toplanması ve içerik analizinin gerçekleştirilmesi süreçlerinin uyumlu bir çerçevede yürütülmesi ile tutarlılık unsuru sağlanmıştır. Araştırmacılar veri analizinde elde edilen bulgular ile verileri sürekli karşılaştırmışlar, bu şekilde doğrulanabilirlik unsunu sağlamaya çalışışlardır. Son olarak araştırmacılar gerçekleştirilen içerik analizi sürecinin güvenirliğini sağlamak için, birbirlerinden bağımsız olarak tespit etmiş oldukları kodlamaları karşılaştırmışlar ve kodlayıcılar arası uyum yüzdesini Miles ve Huberman'ın (1994) Güvenirlik $=\frac{\text { Uyuşan Kod Sayısı }}{\text { Uyuşan Kod Sayısı }+ \text { Uyuşmayan Kod Sayısı }}$ formülünü kullanarak hesaplamışlardır. İki araştırmacının gerçekleştirmiş oldukları analiz sonucundaki uyuşum yüzdesi \%86 olarak hesaplanmıştır. Miles ve Huberman (1994) bu uyuşumun \%80'e yakın ya da üzerinde olması gerektiğini belirtmektedir. Bu doğrultuda kodlayıcılar arası uyumun uygun olduğu ifade edilebilir.

Araştırma sürecinde okul öncesi çocukları ile çalı̧̧masından dolayı, ailelere çalışmanın amaç ve kapsamına ilişkin birer yazı gönderilmiş; sınıf içerisinde hiçbir şekilde video kaydı alınmayacağı, çocukların kimlik bilgilerinin paylaşılmayacağı, yapılacak ses kayıtlarında isimlerinin geçmesi halinde çalışmada bunların başka şekilde kodlanacağına dair bilgilendirmeler yapılmıştır. Ses kayıtlarına ilişkin çocuklarla da görüşme gerçekleştirilmiş, görüşmeler sırasında rahat olmalarını sağlayacak unsurlar yerine getirilmiştir. Görüşmeler bireysel olarak gerçekleştirilmiş ve çocukların birbirilerine olacak muhtemel etkileşimlerinin önüne geçilmiştir.

\section{BULGULAR}

Okul öncesi dönem çocuklarının çevre sorunları kavramına ilişkin sahip oldukları algıların metaforlar ve görüşler aracılığı ile belirlenmesi amacı ile yapılan bu çalışmada katılımcılar tarafından dile getirilen metaforlar benzer olma durumlarına göre temalandırılarak sunulmuştur. Gerekçeleri ise temaya ait kategori olarak sunulmuştur. Bu bağlamda okul öncesi dönem çocuklarının "Çevre sorunları" kavramına ilişkin meydana getirdikleri metaforlar ve bu metaforların yer aldığı kategoriler aşağıda başlıklar halinde sunulmuştur.

Tablo 2. Katılımcıların Çevre Sorunları Kavramına Yönelik Metaforları

\begin{tabular}{ccc}
\hline Tema (Metafor) & Kategori (Neden) & Katılımcı Kodu \\
\hline \multirow{2}{*}{ Kötü Koku } & Çöplerin Doğaya Atılması & Mavi \\
\cline { 2 - 3 } & Hayvanların Doğayı Pislemesi & Bordo \\
\hline \multirow{2}{*}{ Ağlayan Bitki } & A ğaçların Kesilmesi & Pembe \\
\cline { 2 - 3 } & Çiçeklerin Koparılması & Sarı \\
\cline { 2 - 3 } Kara Bulut & Bacalardan Çıkan Kara Bulut & Lacivert, Siyah \\
\cline { 2 - 3 } Mutsuz Hayvan & Arabalardan Çıkan Kara Bulut & Mor, Kırmızı \\
\cline { 2 - 3 } & Hayvanların Avlanması & Beyaz, Gri \\
\hline \multirow{2}{*}{ Mide Bulantısı } & Hayvanların Yok Edilmesi & Turuncu \\
\cline { 2 - 3 } & Hayvanların Kirlilikten Ölmesi & Yeşil \\
\hline
\end{tabular}

Tablo 1 incelendiğinde, katılımcıların çevre sorunlarına yönelik metaforlarının kötü koku, ağlayan bitki, kara bulut, mutsuz hayvan ve mide bulantısı olmak üzere beş tema altında toplandığı görülmektedir. Kötü koku teması çöplerin doğaya atılması ve hayvanların doğayı pislemesi; ağlayan bitki teması ağaçların kesilmesi ve çiçeklerin koparılması; kara bulut teması bacalardan çıkan kara bulut ve arabalardan çıkan kara bulut; mutsuz hayvan teması hayvanların avlanması, hayvanların yok edilmesi ve hayvanların kirlilikten ölmesi; mide bulantısı teması görüntüden kaynaklı bulantı ve kokudan kaynaklı bulantı olmak üzere kategorileri içermektedir. Çevre sorunları kavramına yönelik olarak kötü koku temasına vurgu yapan mavi kodlu katılımcı metaforunu "Çevre sorunları kötü koku gibidir. Çünkü çöpler çeoreye atılıyor. Çöpler kötü kokuyor" şeklinde dile getirirken bordo kodlu katılımcı ise metaforunu "Çevre sorunu kötü/pis kokudur. Ben bir kere pisliğe basmıştım. Hayvan pisliği çevreyi kirletiyor. Çevre sorunudur" şeklinde ifade etmiştir. Çevre sorunlarını ağlayan bitki teması ile tanımlayan pembe kodlu katılımcı metaforunu "Çevremizin sorunu ağlayan ă̆açtır. Çünkü ă̆açlar kesilince ağhıyor. Canları yanıyor. Kesilmek kötü bir şey" şeklinde betimlerken sarı kodlu katılımcı ise "Çevre sorunu, ağlayan/üzülen çiçektir. Çünkü çiçek dururken koparıllyor. 
Koparılınca hemen ağlıyor. Üzülüyor" şeklinde açılamıştır. Çevre sorunları kavramına yönelik olarak kara bulut temasına değinen siyah kodlu katılımcı metaforunu "Çevre sorunu kara buluttur. Çünkü bacalardan çıan siyah bulutlar var" şeklinde dile getirirken mor kodlu katılımcı ise "Çevre sorunları siyah/kara duman buluttur. Arabalar siyah duman yapıyor. Bizi kirletiyor" şeklinde ifade etmiştir. Çevre sorunlarını mutsuz hayvan teması ile tanımlayan beyaz kodlu katılımcı metaforunu "Çevre sorunu mutsuz tavşandır. Çünkü hayvanlar avlanıyor. Ben buna üzülüyorum. Tavşanlar ağhlyor" şeklinde, turuncu kodlu katılımcı "Çevre sorunu mutsuz/keyifsiz hayvanlardır. Yok olmuş öldürülmüş bir sürü hayvan var. Hayvanlar çok mutsuzlar" şeklinde ve kahverengi kodlu katılımcı ise "Çevre sorunu, mutsuz hayvandır. Denizlerin pis ve balıklar ölüyor. Sokak pis ve köpekler ölüyor. Hava pis ve kuşlar ölüyor" şeklinde betimlemiştir. Çevre sorunları kavramına yönelik olarak mide bulantısı temasına vurgu yapan yeşil kodlu katılımcı metaforunu "Çevre sorunları mide bulandırıcıdır. Hayvan pisliğinin çevrede olması. Bahçede görünce midem bulanıyor." şeklinde dile getirirken bej kodlu katılımcı ise metaforunu "Çevre sorunu tamamen mide bulantısıdır. Evin yanındaki çöpleri görünce midem bulanıyor. Çok kötü kokuyor" şeklinde ifade etmiştir.

Araştırma kapsamında ele alınan ikinci tema "Çevre sorunlarında etkili olan durumlar" olarak belirlenmiştir. İlgili duruma yönelik olarak okul öncesi dönem çocuklarına "Çevre sorunlarında etkili olan durumlar nelerdir? Neden böyle düşünüyorsun?" soruları yöneltilmiş ve elde edilen veriler Tablo 3'te sunulmuştur.

Tablo 3. Katılımcıların Çevre Sorunlarında Etkili Olan Durumlar Hakkında Görüşleri

\begin{tabular}{cccc}
\hline Tema & Kategori & Katılımcı Kodu & Yüzde \\
\hline \multirow{2}{*}{ İnsanlardan Kaynaklı } & İnsanların Bencilliği & Pembe & \multirow{2}{*}{50,00} \\
\cline { 2 - 3 } & İnsanların Açgözlülüğ̈̈ & Beyaz, Turuncu & Mavi \\
\cline { 2 - 3 } & İnsanların Akılsızlığı & \multirow{2}{*}{21,42} \\
\cline { 2 - 3 } $\begin{array}{c}\text { Hayvanlardan } \\
\text { Kaynaklı }\end{array}$ & İnsanların Temiz Olmaması & Lacivert, Gri, Sarı & \multirow{2}{*}{28,58} \\
\cline { 2 - 3 } Araçlardanların Çevreyi Pislemesi & Hayvanların Çöpleri Dağıtması & Bordo, Bej & Kahverengi \\
\cline { 2 - 3 } & Araçlardan Çıkan Dumanlar & Siyah, Mor & Yeşil, Kırmızı \\
\hline
\end{tabular}

Tablo 3 incelendiğinde, çevre sorunlarında etkili olan durumların insanlardan kaynaklı, hayvanlardan kaynaklı ve araçlardan kaynaklı olmak üzere üç tema altında toplandığı görülmektedir. İnsanlardan kaynaklı teması insanların bencilliği, insanların açgözlülüğü, insanların akılsızlığı ve insanların temiz olmaması; hayvanlardan kaynaklı teması hayvanların çevreyi pislemesi ve hayvanların çöpleri dağıtması; araçlardan kaynaklı teması ise araçlardan çıkan dumanlar ve araçlardan çıkan sesler kategorilerini içermektedir. Çevre sorunlarının insanlardan kaynaklı olduğuna değinen pembe kodlu katılımcı görüşünü "İnsanlar çok benciller. İstekleri olsun istiyor. Sonra da çeoreyi kirlendi diyorlar" şeklinde, beyaz kodlu katılımcı "Hayvanları öldürüyoruz, ağaçları kesiyoruz. İnsanlar hep açgözlü" şeklinde, mavi kodlu katılımcı "Çevreyi insanlar kirletiyor. Bence insanlar akılsız. Akıllı olsa böyle yapmaz" şeklinde ve gri kodlu katılımcı "Temiz olsak sorun kalmaz. Herkes kendi çöpünü çöpe atsa temiz olur çeore" şeklinde ifade etmiştir. Çevre sorunlarının hayvanlardan kaynaklı olduğunu dile getiren bordo kodlu katılımcı "Hayvanlar istedikleri yeri pisliyor. Bu çevrede yaşanmaz" görüşünü şeklinde ifade ederken kahverengi kodlu katılımcı ise "Hayvanlar kirletiyor. Çöp kutusuna çöp atmıştık. Çıkartıp yere döktüler" şeklinde belirtmiştir. Çevre sorunlarının araçlardan kaynaklı olduğuna vurgu yapan mor kodlu katılımcı görüşünü "Çevreyi kirleten araçlardan çıkan siyah dumandır" şeklinde belirtirken yeşil kodlu katılımcı ise "Bizim arabada olmuyor. Ama bir mavi araba var. Ondan çok ses geliyor. Rahatsız oluyor herkes" şeklinde açıklamıştır.

Araştırma kapsamında ele alınan üçüncü faktör "Çevre sorunlarının etkisi" olarak belirlenmiştir. İlgili duruma yönelik olarak okul öncesi dönem çocuklarına "Çevre sorunlarının etkisi hakkında neler düşünüyorsun? Çevre sorunlarından neler etkilenir?" soruları yöneltilmiş ve elde edilen veriler Şekil 1'de sunulmuştur. 


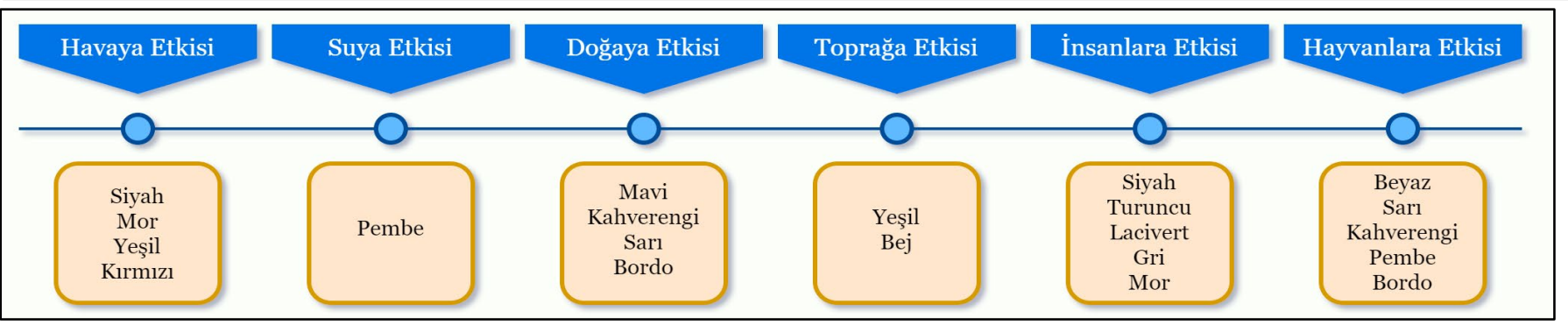

Şekil 1. Katılımcıların çevre sorunlarının etkisine yönelik görüşleri

Şekil 1 incelendiğinde, katılımcıların çevre sorunlarının etkisine yönelik olarak havaya etkisi, suya etkisi, doğaya etkisi, toprağa etkisi, insanlara etkisi ve hayvanlara etkisi olmak üzere altı başlık altında görüşlerini belirttikleri görülmektedir. Çevre sorunlarının havaya etkisine yönelik olarak mor kodlu katılımcı görüşünü “Siyah dumanlar havayı çok kirletiyor. Kışın dışarıda görüyorum siyah dumanları" şeklinde dile getirmiştir. Çevre sorunlarının suya etkisine yönelik olarak pembe kodlu katılımcı görüşünü "Atılan çöpler suyu kirletiyor. Kirli suda balıklar yaşayamaz $k i$ " şeklinde ifade etmiştir. Çevre sorunlarının doğaya etkisine yönelik olarak mavi kodlu katılımcı görüşünü "Çevre sorunlar yüzünden doğa pisleniyor. Ben buna üzülüyorum" şeklinde betimlemiştir. Çevre sorunlarının toprağa etkisine yönelik olarak bej kodlu katılımcı görüşünü "Arkadaşlarım çöpleri topră̆a atıyor. Çöp kutusu uzak kalıyor diye. Sabah geldiğimizde çöp hala toprakta oluyor" şeklinde açıklamıştır. Çevre sorunlarının insanlara etkisine yönelik olarak turuncu kodlu katılımcı görüşünü "Çevreyi kendimiz kirletiyoruz. Kendimiz zarar görüyoruz. Çevreye zarar vermesek zarar görmeyiz" şeklinde dile getirmiştir. Çevre sorunlarının hayvanlara etkisine yönelik olarak bordo kodlu katılımcı görüşünü "Hayvanlar en çok etkileniyor. Çünkü evleri pisleniyor. Ama yaşamak zorundalar. Etkileniyorlar" şeklinde ifade etmiştir.

Araştırma kapsamında ele alınan son faktör "Çevre sorunlarına öneriler" olarak belirlenmiştir. İlgili duruma yönelik olarak okul öncesi dönem çocuklarına "Çevre sorunlarının önüne geçebilmek için neler yapılabilir? Nelere dikkate etmek gerekir?" soruları yöneltilmiş ve elde edilen veriler Şekil 2'de sunulmuştur.

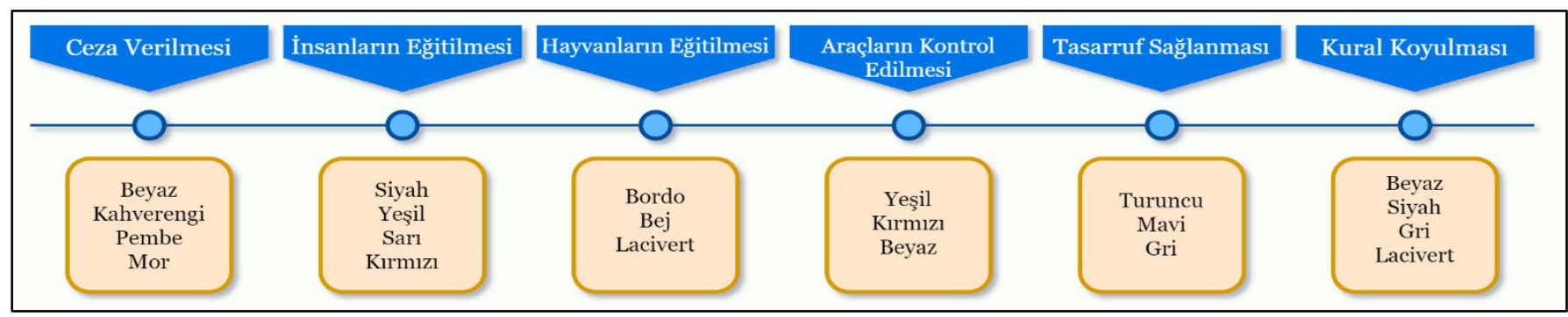

Şekil 2. Katılımcıların çevre sorunlarına yönelik önerileri

Şekil 2 incelendiğinde, katılımcıların çevre sorunlarına yönelik önerileri ceza verilmesi, insanların eğitilmesi, hayvanların eğitilmesi, araçların kontrol edilmesi, tasarruf sağlanması ve kural koyulması olmak üzere altı başlık altında görüşlerini belirttikleri görülmektedir. Çevre sorunlarının giderilmesine yönelik olarak ceza verilmesi kavramına değinen kahverengi kodlu katılımcı görüşünü "Çevreyi kirletenlere ceza verilmelidir. Ama ceza büyük olmall. Küçük ceza olmaz" şeklinde dile getirmiştir. Çevre sorunlarının giderilmesine yönelik olarak insanların eğitilmesi kavramına değinen sarı kodlu katılımcı görüşünü "İnsanlara ă̆aç kesmenin yanlış olduğu söylenmeli. Ağaçları kesmemeliyiz. Çöpleri atmamahıyı. Çevreyi pisletmemeliyiz" şeklinde ifade etmiştir. Çevre sorunlarının giderilmesine yönelik olarak hayvanların eğitilmesi kavramına değinen bordo kodlu katılımcı görüşünü "Hayvanlar eğitilmeli. Dışarıya pislememeleri öğretilmeli. Bisküvi verilebilir" şeklinde betimlemiştir. Çevre sorunlarının giderilmesine yönelik olarak araçların kontrol edilmesi kavramına değinen beyaz kodlu katılımcı görüşünü "Araçlardan çıkan dumanlar bakılmalı. Kontrol edilmeli. Duman çıkmasın" şeklinde açıklamıştır. Çevre sorunlarının giderilmesine yönelik olarak tasarruf sağlanması kavramına değinen turuncu kodlu katılımcı görüşünü "Kâğıtları tasarruflu kullanalım. Ağaç kesmek zorunda olmayız. Kâ̆̆ıtları boşuna kullanmayalım" şeklinde dile getirmiştir. Çevre sorunlarının giderilmesine yönelik olarak kural koyulması kavramına değinen gri kodlu katılımcı görüşünü "Kural koyulmal. Herkes buna uymalı. Ayakkabı ile buraya girmek yasak. Pislenmesin diye. Bunun gibi kurallar" şeklinde ifade etmiştir.

|Manisa Celal Bayar University Journal of The Faculty of Education, 2021, Vol. 9, No. 1 | 


\section{TARTIŞMA}

Gerçekleştirilen bu araştırmada okul öncesi dönem çocuklarının "çevre sorunları" kavramına yönelik metaforları ve görüşleri belirlenmiştir. Okul öncesi çocuklarının çevre sorunu olarak beş tema altında toplam 11 metafora sahip oldukları görülmektedir. Çocukların çevre sorunu olarak hayvanların türlerinin gördügü zararlara (avlanma, yok edilme, kirlilikten ölme) ile fabrikalar ve araçlardan çevreye yayılan sera gazlarına (kara bulut) ilişkin metaforlara sahip oldukları $(\% 28,58)$ tespit edilmiştir. Yine ağlayan bitki teması altında ormanların zarar görmesi; kötü koku ve mide bulantısı teması altında ise çevresel kirliliğe ilişkin metaforlara sahip oldukları görülmektedir. Çocukların genel bağlamda etrafında yaşayan bitki ve hayvanlara ilişkin metaforlara sahip oldukları, ek olarak bunlara zarar veren unsurlara da değindikleri belirlenmiştir. Çocukların akıllarına gelen ilk metaforun çevrelerindeki bitki ve hayvanlar olmasına ilişkin duruma Bonnett ve Williams (2006), Burgess ve Smith (2011) ve Yardımcı'nın (2009) çalışmalarında rastlanmaktadır. Bitki ve hayvanlara ilişkin temaların yanında kötü koku, mide bulantısı ve kara bulut temaları bir bütün olarak değerlendirilecek olursa, çocukların karşılaştıkları somut durumlara ilişkin metaforlara sahip oldukları ifade edilebilir. Bilişsel gelişim kuramına göre işlem öncesi dönemde bulunan okul öncesi çocuklarının, sadece fiziksel olarak karşılaştıkları durumları içselleştirebilmeleri (Yüksel, 2015), araştırma neticesinde belirlenen çevre sorunu kavramına ilişkin metaforlarının da yüzeysel kalmasının bir sonucu olarak değerlendirilebilir. Diğer yandan Tablo 2'de yer alan tema ve kategorilere bakıldığında, çocukların sahip oldukları metaforların (kötü koku, mide bulantısı, dumanların kendisini kirletmesi gibi) kendilerini etkileyen durumlar olduğu görülmektedir. Yine çocukların bulundukları bilişsel dönem göz önünde bulundurulduğunda, benmerkezcil algılayışa sahip çocukların (Ak-Mert, 2007) çevre sorunları kavramına ilişkin ifade ettikleri metaforlar bu durumun doğal bir sonucu olarak yorumlanabilir.

Okul öncesi dönem çocuklarının çevre sorunlarının kaynaklarına ilişkin görüşlerine bakıldığında çoğunluğun (\%50) sebep olarak insan kaynaklı davranışları ifade ettikleri görülmektedir. İnsan kaynaklanan çevre sorunlarının ise daha çok insanların temiz olmamasına ve insanların hep kendi istediklerinin olmasına bağladıkları belirlenmiştir. Lacivert, gri ve sarı renk kodlu çocuklar insanların çöpleri etrafa atarak çevreye zarar verdiklerini belirtirken, mavi kodlu çocuk insanların çevreyi kirletmelerinin sonucunu fark etmediklerini belirtmiş ve çevreyi kirletenleri "akılsız" olarak ifade etmiştir. Çocukların yarısının çevre sorunlarına ilişkin gerekçe olarak insan kaynaklı davranışlara verdikleri bu örnekler, onların insanların çevreyle olan sürekli etkileşimlerini algılamalarından kaynaklanan muhtemel bir sebeptir. Literatüre bakıldığında bu durumla benzer çalışmalara rastlanmaktadır. Örneğin Özsoy (2012) ilköğretim öğrencileri ile gerçekleştirmiş olduğu çalışmasında, çevre algılarına ilişkin resimlerde insanlara yer verdiklerini ve insanı, çevrenin bir paydaşı olarak betimlediklerini belirtmektedir. Dunlap, van Liere, Mertig ve Jones (2000) ise insan-çevre etkileşiminin yorumlanmasındaki ana unsuru yorumlayabilmek için, bireylerin çevreye yönelik algılarının önemine vurgu yapmaktadır. Diğer yandan literatürde yer alan bazı çalışmalarda (Ahi ve Alisinanoğlu, 2016; Lougland, Reid ve Petocz, 2002; Moseley, Desjean-Perrotta ve Utley, 2010) okul öncesi çocukların insanı çevrenin bir öğesi olarak yorumlamadıkları, çevreyle bir bütün oluşturan paydaş olarak görmediklerine ilişkin sonuçlara da rastlanmaktadır. Bu araştırmada ise çocukların insanları, çevreden bağımsız olarak düşünmedikleri ifade edilirse, aslında ekosentrik (doğa merkezli) bir yaklaşıma sahip oldukları, bu bağlamda arzu edilen çevre algısı temelinin zihinlerinde yer aldığı söylenebilir.

Araştırma kapsamında çocukları çevre sorunlarının etkilerine ilişkin verdikleri cevaplar incelendiğinde, insan ve hayvanlara yönelik açıklamaların sıklığı göze çarpmaktadır. Bu unsurları sıklık oranıyla birlikte hava, doğa, toprak ve su takip etmektedir (Bkz. Şekil 1). Çocukların ifadelerine bakıldığında, çevre sorunlarından etkilenen öğelerin birbirinden bağımsız olarak açıklandığı gözlemlenmektir. Yani çocuklar ekolojiyi oluşturan unsurları, ayrı ayrı belirtebilmiş ve bunların çevresel sorunlardan etkilenmelerine ilişkin açıklamalar yapabilmiş olsalar da ilgili öğelerin birbirleri ile olan ilişkileriyle alakalı ifadelere yer veremedikleri görülmektedir. Bu durum 58-66 yaş grubu çocukları için bilişsel bağlamda normal olarak yorumlanabilir. Literatürde yer alan çalışmalarda da benzer durumlar söz konusudur (Liu ve Lin, 2015; Moseley, Desjean-Perrotta ve Utley, 2010; Vosniadou ve Brewer, 1994). Okul öncesi dönem çocuklarının, diğer bir ifadeyle işlem öncesi dönemde bulunan çocukların karmaşık ilişki ağları kurabilmeleri 
ve bunları zihinlerinde yapılandırmaları beklenmeyen bir durumdur (Brewer, 2006). Bu araştırma sonuçları literatürü teyit eder şekilde belirlenmiş olsa da araştırmacılar bu durumun doğru bir eğitim süreciyle engellenerek, bütünü oluşturan unsurlar arası ilişkilerin korunmasını sağlayacak deneyimlerin gerçekleştirilmesini vurgulamaktadırlar (Hatano ve İnagaki, 1997; Vosniadou ve Brewer, 1994).

Araştırma kapsamında elde edilen bulgular neticesinde okul öncesi çocuklarının çevre sorunlarını önleyici görüşlerine bakıldığında kural koyma, çevreyi kirletenlere yönelik ceza verme, insanlara çevre eğitimleri verilmesi, atmosfere salınan sera gazlarının kontrol edilmesi gibi unsurlara değindikleri görülmektedir. Kural koyma ve ceza verme gibi davranışçı yaklaşıma ait öğelerin sekiz çocuk tarafından belirtiliyor olması, geçmiş yaşamlarındaki deneyimlerinin bu yönde bir neden-sonuç ilişkisi kurmalarına sebep olduğu söylenebilir. Taşkın (2004) okul öncesi döneminde verilen eğitimin, çocukların çevreye yönelik tutumlarında önemli bir yere sahip olduğu belirtmektedir. Dolayışla, araştırma kapsamında çocukların çevre sorunlarına yönelik olarak belirtmiş oldukları ceza ve kural önerileri, ailelerin vermiş oldukları informal eğitimden ve anaokulunda verilen formal eğitimden kaynaklanıyor olabilir. Diğer yandan insanların ve hayvanların çevreyi kirletmemelerine yönelik olarak eğitilmeleri ile tasarrufa yönelik önlemler alınması gerektiği de bazı çocuklar tarafından belirtilmektedir. Bu önerilerin nispeten yüksek bir çevre algısı ile oluşturulabileceği ifade edilebilir. Literatür incelendiğinde çocukların çevreye yönelik bakış açılarını ya da algılarını sosyo-ekonomik düzeyin önemli derecede etkilediği belirtilmektedir (Loughland vd., 2003). Araştırma kapsamında yer alan çocukların özel bir okula devam ediyor olmaları, yüksek sosyo-ekonomik düzey ailelerden geliyor olmalarına yordanabilir.

\section{SONUÇ ve ÖNERİLER}

Bu araştırma kapsamında 58-66 aylık çocukların "çevre sorunları" kavramına yönelik metaforik algıları ve bu kavrama yönelik çeşitli görüşleri belirlenmiştir. Araştırma neticesinde çocukların çevre sorunu kavramını ilişkin oluşturdukları metaforların deneyimledikleri, karşılaştıkları ve kendilerini rahatsız eden öğe ya da nesneleri kullanarak ifade ettikleri sonucuna ulaşılmıştır. Bu durum çocukların henüz deneyimlemedikleri ya da tek başlarına algılamalarının mümkün olmadığı diğer çevre sorunlarına ilişkin metaforlar oluşturamayacaklarını yordayan bir unsur olabilir. Dolayısıyla bu dönemde yer alan çocuklara, kendi bilişsel düzeyleri göz önünde bulundurularak verilecek çevre eğitimleriyle, çevre sorunlarına ilişkin daha geniş perspektif kazandırılacak içeriklerin sunulması önerilmektedir. Ayrıca, araştırma kapsamında yer alan çocukların çevreye yönelik etkinlikler yürütmeleri ve çevre kavramına yönelik bir farkındalıklarının olması, çevre sorunları kavramına yönelik metafor oluşturabilmelerine ve çeşitli görüşler ifade edebilmelerine olanak sağlamıştır. Bu sonuç doğrultusunda, çevreye yönelik olumlu tutum ve davranışlar geliştirmede okul öncesi dönemin önemi göz önünde bulundurulduğunda, çevre eğitimine erken yaşlarda başlanması önerilmektedir.

Araştırmaya katılan çocuklar özel bir okulun anaokulunda eğitim görmektedirler. Bu durum onların hem sosyo-ekonomik düzeylerinin hem de almış oldukları formal eğitimin nitelikli olduğunun bir yordayıcısı olarak görülebilir. Çocukların çevre sorunlarına ilişkin oluşturdukları metaforlar, bu çevre sorunlarının kaynakları olarak belirtmiş oldukları unsurlar, çevre sorunlarına yönelik ifade ettikleri öneriler bunun bir göstergesi olarak ifade edilebilir. Dolayısıyla, farklı sosyo-ekonomik düzeyde olan ailelerin çocuklarıyla da farklı çalışmaların yürütülmesi ve literatürle karşılaştırmalı sonuçların irdelenmesi önerilmektedir.

Bu araştırma kapsamında veri toplama süreci, 58-66 aylık yaş grubunda yer alan çocuklarla gerçekleştirilmiş olup, veriler görüşmeler aracılığıyla toplanmıştır. Okul öncesi dönem çocuklarından farklı veri toplama yöntemleri (resim çizdirme vb.) de kullanılarak çevre sorunlarına ilişkin zihinsel imajları ortaya konabilir. Ayrıca farklı yaş grupları ile bu çalışma kapsamında belirlenen yaş grubuna ait bireylerinin de içinde bulunduğu gelişimsel (enlemsel) çalışmalar yürütülerek, gelişim ve bilişsel düzeylerin çevre sorunlarına bakış açılarını inceleyen çalışmalar yürütülebilir. 
KAYNAKÇA

Ahi, B., \& Alisinanoğlu, F. (2016). Okul öncesi eğitim programına kaynaştııılan çevre eğitimi programının çocukların" çevre" kavramı hakkındaki zihinsel model gelişimine etkisi. Kafkas Üniversitesi Sosyal Bilimler Enstitüsü Dergisi, 18, 305-329.

Akgün, A., Duruk, Ü. \& Gülmez-Güngörmez, H. (2016). Ortaokul öğrencilerinin çevre eğitimi kavramına yönelik metaforları. Dicle Üniversitesi Ziya Gökalp Eğitim Fakültesi Dergisi, 28, 215-224.

Akın, G. (2006). Küresel 1sınma, nedenleri ve sonuçları. Ankara Üniversitesi Dil ve Tarih-Coğrafya Fakültesi Dergisi, $46(2), 29-43$.

Ak-Mert, Ö. (2007). Jean Piaget düşüncesinde psikolojik yapılar (Yayımlanmamış Yüksek Lisans Tezi). Gazi Üniversitesi Eğitim Bilimleri Enstitüsü, Ankara.

Atasoy, E. (2006). Çevre için eğitim, çocuk doğa etkileşimi. Bursa: Ezgi Kitabevi.

Aydın, F. (2011). Üniversite öğrencilerinin çevre kavramına ilişkin metaforik algıları. Doğu Coğrafya Dergisi, 16(26), 25-44.

Basile, C. G. (2000). Environmental education as a catalyst for transfer of learning in young children. The Journal of Environmental Education, 32(1), 21-27.

Bonnett, M. \&, Williams, J. (2006). Environmental education and primary children's attitudes towards nature and the environment. Cambridge Journal of Education, 28(2), 159-174.

Bozoğlu, B., Keskin, B. \& Çavdar, S. (2003). Küresel ısınma. 6. Çevre Sorunları Öğrenci Yaklaşımları Sempozyumu, Nisan 2003. Mersin.

Brewer, J. A. (2001). Introduction to early childhood education: Preschool through primary grades. Boston: Allyn and Bacon.

Burgess, J. \&, Smith, M. J. (2011). Listening to children: Perceptions of nature. The Journal of Natural History Education and Experience, 5, 27-43.

Cohen, L., \& Manion, L. (1994). Research methods in education (Fourth edition). Newyork: Rutledge.

Çepni, S. (2010). Araştırma ve proje çalı̧̧malarına giriş. Trabzon: Ofset Matbaacıllk.

Çil, D. (2018). Ortaokul öğrencilerinin temel fizik kavramlarına yönelik metaforik algılarının incelenmesi. (Yayımlanmamış Yüksek Lisans Tezi). Kırıkkale Üniversitesi, Fen Bilimleri Enstitüsü, Kırıkkale.

Deniz, L. (2020). Okulöncesi (4-6 yaş grubu) çocuk resimlerinde çevre algısı ve çocuk çevrelerinin sağlaması gereken özellikler. (Yayımlanmamış Yüksek Lisans Tezi). Karadeniz Teknik Üniversitesi, Fen Bilimleri Enstitüsü, Trabzon.

Derman, A. (2014). Lise öğrencilerinin kimya kavramına yönelik metaforik algıları. Turkish Studies - International Periodical For The Languages, Literature And History Of Turkish Or Turkic, 9(5),749-776. http://dx.doi.org/10.7827/TurkishStudies.6738

Dunlap, R. E., Van Liere, K. D., Mertig, A. G., \& Jones, R. E. (2000). New trends in measuring environmental attitudes: measuring endorsement of the new ecological paradigm: A revised NEP scale. Journal of social issues, 56(3), $425-442$.

Erten, S. (2004). Çevre eğitimi ve çevre bilinci nedir, çevre eğitimi nasıl olmalıdır. Çevre ve İnsan Dergisi, 65-66, 83-94.

Ferah, A. (2007). Türkçe ilkokuma yazmayı öğrenme. Ankara: Nobel Yayın Dağıtım.

Forceville, C. (2002). The identification of target and source in pictorial metaphors. Journal of Pragmatics, 34, 1-14.

Gülay, H. \& Önder, A. (2011). Sürdürülebilir gelişim için okulöncesi dönemde çeore eğitimi. Ankara: Nobel Yayın Dağıtım.

Gülay-Ogelman, H., \& Güngör, H. (2015). Türkiye'deki okul öncesi dönem çevre eğitimi çalışmalarının incelenmesi: 2000-2014 yılları arasındaki tezlerin ve makalelerin incelenmesi. Mustafa Kemal Üniversitesi Sosyal Bilimler Enstitüsü Dergisi, 12(32), 180-194. 
Güler, T. (2008). Okul öncesi eğitime giriş. G. Haktanır (Edt.). Okul öncesi eğitimde ailenin önemi ve okul aile işbirliği içinde (s. 295-322). Ankara: Anı Yayıncıllk.

Hatano, G., \& Inagaki, K. (1997). Qualitative changes in intuitive biology. European Journal of Psychology of Education, 12(2), 111-130.

Hatch, J. A. (2002). Doing qualitative research in education settings. Albany: State University of New York Press.

Hedefalk, M., Almqvist, J., \& Östman, L. (2015). Education for sustainable development in early childhood education: A review of the research literature. Environmental Education Research, 21(7), 975-990. https://doi.org/10.1080/13504622.2014.971716

Kızılay, E. (2020). Sınıf öğretmeni adaylarının çevre sorunlarına yönelik metaforik algılarının incelenmesi. Avrasya Uluslararası Araştırmalar Dergisi, 8(21), 230 - 240.

Kuzu, T. (2008). Aytül Akal'ın masallarıyla çocukta çevre bilinci geliştirme. Selçuk Üniversitesi Sosyal Bilimler Enstitüsü Dergisi, 19, 327-339.

Lakoff G., \& Johnson M. (2005). Metaforlar: Hayat, anlam ve dil (G. Y. Demir, Çev.). İstanbul: Paradigma Yayınları.

Lincoln, Y. S., \& Guba, E. G. (1985). Naturalistic inquiry. Newbury Park: Sage Publications.

Liu, S. C., \& Lin, H. S. (2014). Undergraduate students' ideas about nature and human-nature relationships: an empirical analysis of environmental worldviews. Environmental Education Research, 20(3), 412-429.

Loughland, T., Reid, A., Walker, K., \& Petocz, P. (2003). Factors influencing young people's conceptions of environment. Environmental Education Research, 9(1), 3-19.

Marton, F. (1994). Phenomenography. In T. Hus_en, G. Handal, \& T. N. Postlethwaite (Eds.), The international encyclopedia of education (2nd ed., pp. 4424-4429). Oxford, UK: Pergamon Press.

Miles, M.B., \& Huberman, A.M. (1994). Qualitative data analysis: An expanded sourcebook (2nd Ed.). London: Sage Publications.

Morgan, G. (1993). Imaginization. The Art of Creative Management. California: Sage Publications.

Moseley, C., Desjean-Perrotta, B., \& Utley, J. (2010). The draw-an-environment test rubric (DAET-R): Exploring preservice teachers' mental models of the environment. Environmental Education Research, 16(2), 189-208.

Ogelman, H. G., Önder, A., Durkan, N., \& Erol, A. (2015). Investigation of the efficiency of "We are learning about the soil with Tipitop and his friends 6" entitled soil education project. International Journal of Social Sciences and Education Research, 1(2), 476-488.

Özdemir, O., \& Uzun, N. (2006). Yeşil sınıf modeline göre yürütülen fen ve doğa etkinliklerinin ana sınıfı öğrencilerinin çevre algılarına etkisi. Çocuk Gelişimi ve Ĕ̆itimi Dergisi, 3(1-2), 12-20.

Özsoy, S. (2012). İlköğretim öğrencilerinin çevre algılarının çizdikleri resimler aracıllğıyla incelenmesi. Kuram ve Uygulamada Ĕ̆itim Bilimleri, 12(2), 1117-1139.

Öztürk, K. (2002). Küresel iklim değişikliği ve Türkiye’ye olası etkileri. Gazi Üniversitesi Gazi Eğitim Fakültesi Dergisi, 22(1). 47-65.

Phenice, L. A., \& Griffore, R. J. (2003). Young children and the natural world. Contemporary Issues in early childhood, $4(2), 167-171$.

Saban, A. (2008). Okula ilişkin metaforlar. Kuram ve Uygulamada Eğitim Yönetimi, 55(55), 459-496.

Şallı, D. (2011). Proje tabanlı öğrenme yaklaşımı ile 48-60 aylık çocuklara geri dönüşüm kavramının kazandırılması. (Yayınlanmamış Yüksek Lisans Tezi). Marmara Üniversitesi Eğitim Bilimleri Enstitüsü, İstanbul.

Taşkın, Ö. \& Şahin, B. (2008). “Çevre” kavramı ve altı yaş okul öncesi çocuklar. Pamukkale Üniversitesi Eğitim Fakültesi Dergisi, 23(1), 1-12. 
Taşkın, Ö. (2004). Postmaterialism, new environmental paradigm and ecocentric approach: A qualitative and quantitative study of environmental attitudes of Turkish senior high school students. (Unpublished Doctoral Dissertation). Indiana University, Bloomington, IN.

Toplu, H. (2015). 8. sinıföğrencilerinin fen ve teknoloji dersine yönelik metaforik algıları. (Yayımlanmamış Yüksek Lisans Tezi). Hacettepe Üniversitesi, Eğitim Bilimleri Enstitüsü, Ankara.

Vanderstoep, S. W., \& Johnson, D. D. (2009). Research methods for everyday life: Blending qualitative and quantitative approaches. San Francisco: John Wiley \& Sons.

Vosniadou, S., \& Brewer, W. F. (1994). Mental models of the day/night cycle. Cognitive science, 18(1), 123-183.

Vosniadou, S., \& Ortony, A. (1989). Similarity and analogical reasoning. Cambridge: Cambridge University Press.

Wellington, J. (2000). Educational research, contemporary issues and practical approaches. London: Continuum.

Wilson, R. A. (1996). Environmental education programs for preschool children. Journal of Environmental Education, 27(4), 28-33.

Yardımcı, E. (2009). Yaz bilim kampında yapılan etkinlik temelli doğa eğitiminin ilköğretim 4 ve 5. Sınıftaki çocukların doğa algılarına etkisi. (Yayımlanmamış Yüksek Lisans Tezi), Abant İzzet Baysal Üniversitesi Sosyal Bilimler Enstitüsü, Bolu.

Yüksel, G. (2015). Yaşam boyu gelişim. Ankara: Nobel. 


\section{Extended Abstract}

\section{Introduction}

It is expected that children who come to a world where serious consequences of global climate problems are observed, have high awareness of environmental problems and their behaviors will be more conscious and sensitive (Hedefalk, Almqvist, \& Östman, 2014). Based on this situation, it can be said that the environmental education to be given to individuals should start in the pre-school period. Because, according to Basile (2000), attitudes towards nature and the development of environmental behaviors begin to take shape in the preschool period.

Many studies indicating the beginning of environmental education in the preschool period are included in the literature (Basile, 2000; Gülay-Ogelman \& Güngör, 2015; Hedefalk et al., 2014; Wilson, 1996). To establish the theoretical structure of environmental education and to ensure that the application process is qualified, first, it is important to determine the mental processes and perceptions of the individual towards the environment. When the literature is examined, it is seen that one of the ways used in determining these perceptions is metaphors (Akgün, Duruk, \& Gülmez-Güngörmez 2016; Aydın, 2011; Çil, 2018; Derman, 2014; Kızllay, 2020; Toplu, 2015). According to Morgan (1993), metaphor is a way of thinking and seeing. Lakoff and Johnson (2005), on the other hand, evaluate metaphor as a tool of mental development and state that it is a form of individual's understanding, not only a word figure, but also an element of thought.

Preschool age individuals who are faced with global environmental problems as early as childhood, perceive the current situation and evaluate these are very important in terms of shedding light on the positive attitudes and behaviors that are expected to develop in them. The metaphors that the concept of environmental problem will form in the minds of children will enable them to take more concrete steps towards this concept in the future and to gain behaviors with a high environmental awareness. Therefore, the purpose of this study is to determine the metaphorical perceptions and views of preschool children towards the concept of environmental problems.

\section{Method}

Since the study aims to determine the metaphorical perceptions and views of preschool children towards the concept of environmental problems, it was conducted with the phenomenographic research method, one of the qualitative research methods. This research method is used to determine a phenomenon that the individual perceives, experiences, constructs, conceptualizes, or understands from different perspectives in the environment in which he lives, using qualitative means (Marton, 1986). The study group consists of 14 children, seven girls and seven boys, between 58-66 months, studying in the kindergarten of a private school in the city center of Trabzon in the spring semester of 2018-2019. In studies where the phenomenographic method is preferred, data collection techniques obtained from individual interviews are frequently preferred (Marton, 1994). It is stated that there are three different types of these interview techniques: informal, guided, and structured (Vanderstoep \& Johnson, 2009). In this study, data were collected using the guided interview technique, since both the order and systematics of the structured interview type and the informal interview type include the free features provided to the researcher. In this context, a form consisting of sentences was developed to determine the metaphorical perceptions of the concept of environmental problems and questions to determine their views. The metaphor sentence in the form: "Environmental problems are like... Because...". The questions used to determine the views are "What are the factors affecting environmental problems?", "Why do you think that?", "What do you think about the impact of environmental problems? What / who are affected by environmental problems?" and "What can be done to prevent environmental problems? What should be considered?" in the form.

The data obtained from the interviews were transcribed and transferred to the computer environment as text. After the data obtained were made suitable for analysis, they were analyzed independently by two researchers. In the process of data analysis, an inductive method was followed by using content analysis. The percentage of agreement in the results of the analysis carried out by the two researchers was calculated as $86 \%$. Miles and 
Huberman (1994) state that this agreement should be close to or above $80 \%$. Accordingly, it can be stated that the percentage of agreement between encoders is suitable.

\section{Findings}

In this study, which was conducted with the aim of determining the perceptions of preschool children about the concept of environmental problems through metaphors and opinions, the metaphors expressed by the participants were presented by theming according to their similarity. It is seen that the metaphors of the participants regarding environmental problems are grouped under five themes: bad smell, weeping plant, black cloud, unhappy animal, and nausea. Bad smell contact waste disposal and animals pollute the nature; weeping plant contact cutting down trees and plucking flowers; black cloud theme dark cloud coming out of chimneys and dark cloud coming out of cars; unhappy animal contact hunting animals, destroying animals and dying animals from pollution; Nausea contact includes categories such as visual nausea and odor-induced nausea.

The second theme addressed within the scope of the research was determined as "Situations that are effective in environmental problems". It is seen that the situations that are effective in environmental problems are gathered under three themes, which are caused by humans, caused by animals, and caused by vehicles. The theme of caused by humans is the selfishness of the people, the greed of the people, the folly of the people and the uncleanness of the people; caused by animals polluting the environment and animals scattering the garbage; The caused by vehicles theme includes the categories of smoke from vehicles and sounds from vehicles.

The third factor addressed within the scope of the research was determined as "The effect of environmental problems". It is seen that the participants stated their opinions regarding the impact of environmental problems under six headings: the effect on the air, the effect on the water, the effect on the nature, the effect on the soil, the effect on humans and on the animals.

The last factor considered within the scope of the research was determined as "Suggestions for environmental problems". It is seen that the participants expressed their opinions under six headings: punishment for environmental problems, education of people, training of animals, controlling vehicles, saving, and setting rules.

\section{Result and Discussion}

It was determined that children have metaphors about plants and animals living around them in general context, in addition, they also touch on the elements that harm them. The first metaphor that comes to children's minds is the plants and animals around them, which is encountered in the studies of Bonnett and Williams (2006), Burgess and Smith (2011) and Yardımc1 (2009). In addition to the themes related to plants and animals, if the themes of bad smell, nausea and black cloud are considered as a whole, it can be stated that children have metaphors about the concrete situations they encounter. It is seen that the metaphors children have (bad smell, nausea, smoke pollution) are situations that affect them. Again, considering the cognitive period the children are in, the metaphors expressed by children with egocentric perception (Ak-Mert, 2007) regarding the concept of environmental problems can be interpreted as a natural consequence of this situation.

The examples that half of the children give to human-induced behavior as a justification for environmental problems are a possible reason arising from their perception of people's continuous interactions with the environment. When the literature is examined, similar studies can be found with this situation. For example, Özsoy (2012), in his study with primary school students, states that they include people in pictures of environmental perceptions and describe people as a stakeholder of the environment. Looking at the statements of the children, it is observed that the elements affected by environmental problems are explained independently from each other. In other words, although the children were able to specify the elements that make up ecology separately and made explanations about their being affected by environmental problems, it is seen that they could not make statements about the relations of the relevant elements with each other. This situation can be interpreted as normal in the cognitive context for children aged 58-66. 
As a result of the findings obtained within the scope of the research, it is seen that preschool children touched on factors such as setting rules, punishing environmental problems, providing environmental education to people, controlling greenhouse gases released into the atmosphere, when looking at their views on preventing environmental problems. It can be said that the elements of behavioral approach such as setting rules and punishment were specified by eight children, causing them to establish a cause-effect relationship in this direction from their past experiences.

\section{Araştırmanın Etik Taahhüt Metni}

Yapılan bu çalışmada bilimsel, etik ve alıntı kurallarına uyulduğu; toplanan veriler üzerinde herhangi bir tahrifatın yapılmadığı, karşılaşılacak tüm etik ihlallerde "Manisa Celal Bayar Üniversitesi Eğitim Fakültesi Dergisi ve Editörünün" hiçbir sorumluluğunun olmadığı, tüm sorumluluğun Sorumlu Yazara ait olduğu ve bu çalışmanın herhangi başka bir akademik yayın ortamına değerlendirme için gönderilmemiş olduğu sorumlu yazar tarafından taahhüt edilmiştir. 